\title{
Estimation of lactic acid bacterial cell number by DNA quantification
}

\author{
Masaki Ishii ${ }^{1}$, Yasuhiko Matsumoto ${ }^{2}$, Kazuhisa Sekimizu ${ }^{1,2, *}$ \\ ${ }^{1}$ Genome Pharmaceuticals Institute Co., Ltd., Tokyo, Japan; \\ ${ }^{2}$ Teikyo University Institute of Medical Mycology, Tokyo, Japan.
}

\begin{abstract}
Summary Lactic acid bacteria are provided by fermented foods, beverages, medicines, and supplements. Because the beneficial effects of medicines and supplements containing functional lactic acid bacteria are related to the bacterial cell number, it is important to establish a simple method for estimating the total number of lactic acid bacterial cells in the products for quality control. Almost all of the lactic acid bacteria in the products are dead, however, making it difficult to estimate the total number of lactic acid bacterial cells in the products using a standard colonycounting method. Here we estimated the total lactic acid bacterial cell number in samples containing dead bacteria by quantifying the DNA. The number of viable Enterococcus faecalis 0831-07 cells decreased to less than $1 \times 10^{-8}$ by 15 min of heat treatment at $80^{\circ} \mathrm{C}$. The amount of extracted DNA from heat-treated cells was $78 \%$ that of non-heated cells. The number of viable Lactobacillus paraplantarum 11-1 cells decreased to $1 \times 10^{-4}$ after 4 days culture. The amount of extracted DNA of the long-cultured cells, however, was maintained at $97 \%$. These results suggest that cell number of lactic acid bacteria killed by heat-treatment or long-term culture can be estimated by DNA quantification.
\end{abstract}

Keywords: Lactic acid bacteria, medicines, supplements, DNA quantification, total cell number estimation

\section{Introduction}

Lactic acid bacteria have various functions, such as digestive functions and immunostimulation, which are considered to be beneficial for maintaining human health (1). Functional lactic acid bacteria are provided as fermented foods, such as yogurt, pickles, and fermented juices, as well as in medicines and supplements $(2,3)$. We previously screened functional lactic acid bacteria using a unique evaluation system utilizing silkworms as experimental animals (4-8).

During the course of those studies, we realized that the development of a simple method for estimating the total number of lactic acid bacterial cells in samples is important for validation of foods and supplements containing functional lactic acid bacteria. The total number of lactic acid bacterial cells in samples is the sum of viable and dead cells. Measuring the number of

\footnotetext{
*Address correspondence to:

Dr. Kazuhisa Sekimizu, Teikyo University Institute of Medical Mycology. 359 Otsuka, Hachioji, Tokyo, 192-0395, Japan.

E-mail: sekimizu@main.teikyo-u.ac.jp
}

viable cells is relatively easy by spreading appropriately diluted samples on agar plates, incubating the plates, and counting the resulting colonies. The number of viable cells is substantially decreased, however, by longterm culture or sterilization during the manufacturing the process. Therefore, a simple method for determining the total cell number of lactic acid bacteria is desired. The use of a dye that stains lactic acid bacteria (9) or an antibody against lactic acid bacteria was proposed for measuring the number of lactic acid bacteria $(10,11)$. These methods, however, may be problematic, requiring special instruments and complicated techniques, and having limited application to specific lactic acid bacteria species.

DNA quantification has been proposed for estimating the total number of bacterial cells in samples containing both viable and dead cells (12). A possible problem in applying this method to lactic acid bacteria is a decrease in the amount of DNA due to its degradation during long-term culture or sterilization. In the present study, we show that the amount of DNA from lactic acid bacteria is still maintained under conditions in which viable cells were decreased. Our results suggest that the total bacterial number of lactic acid bacteria can be estimated 
by DNA quantification.

\section{Materials and Methods}

\subsection{Lactic acid bacteria used in this study}

Leuconostoc paraplantarum 11-1 (4) and Enterococcus faecalis 0831-07 are the lactic acid bacteria isolated in our laboratory.

\subsection{Preparation of lactic acid bacteria}

Glycerol stocks of lactic acid bacteria kept at $-80^{\circ} \mathrm{C}$ were thawed at room temperature and spread on MRS (de Man, Rogosa, Sharpe) agar plates, followed by culture at $30^{\circ} \mathrm{C}$. The emerged colonies were cultured in MRS medium at $30^{\circ} \mathrm{C}$ in a bottle. Cells were heattreated by placing full-growth cell cultures at $80^{\circ} \mathrm{C}$ for $15 \mathrm{~min}$

\subsection{Measurement of viable cell number}

A $100-\mu \mathrm{L}$ aliquot of lactic acid bacteria culture was diluted in saline and spread on an MRS agar plate. After incubation at $30^{\circ} \mathrm{C}$, the number of colonies was counted, and number of viable cells in the sample was calculated.

\subsection{DNA quantification}

Bacterial cells were harvested from $1.5 \mathrm{~mL}$ of culture, washed with $1 \mathrm{~mL}$ saline, and pelleted by centrifugation, and then the cell pellets were suspended in $0.6 \mathrm{~mL}$ of DNA extraction buffer ( $20 \mathrm{mM}$ Tris-HCl ( $\mathrm{pH} \mathrm{8.0),} 25$ mM EDTA, $250 \mathrm{mM} \mathrm{NaCl}, 1 \%$ SDS). The suspension was mixed with $0.5 \mathrm{~mL}$ zirconium oxide beads (Yasui Kikai Corporation, Osaka, Japan) and the cells were homogenized using a bead-type homogenizer (Yasui Kikai Corporation, Osaka, Japan) at 2,500 rpm for $5 \mathrm{~min}$. The samples were mixed with $0.5 \mathrm{~mL}$ phenol/chloroform/ isoamyl alcohol, shaken vigorously, and centrifuged at $12,000 \mathrm{rpm}$ for $5 \mathrm{~min}$. The aqueous layer was collected and washed with $0.5 \mathrm{~mL}$ of chloroform, followed by ethanol precipitation. Precipitates were dissolved in 100 $\mu \mathrm{L}$ Tris-EDTA buffer and treated with $50 \mu \mathrm{g} / \mathrm{mL}$ RNaseA (NIPPON GENE CO., LTD, Toyama, Japan). Samples were extracted with phenol/chloroform/isoamyl alcohol followed by ethanol precipitation. The sample was dissolved in $100 \mu \mathrm{L}$ of Tris-EDTA buffer. The amount of DNA was determined by fluorometric determination (Qubit ${ }^{\mathrm{TM}}$ dsDNA HS Assay Kit, Invitrogen) based on the detection of DNA-specific fluorescence.

\section{Results}

3.1. Relationship between amount of DNA and viable cell number of exponentially growing cells

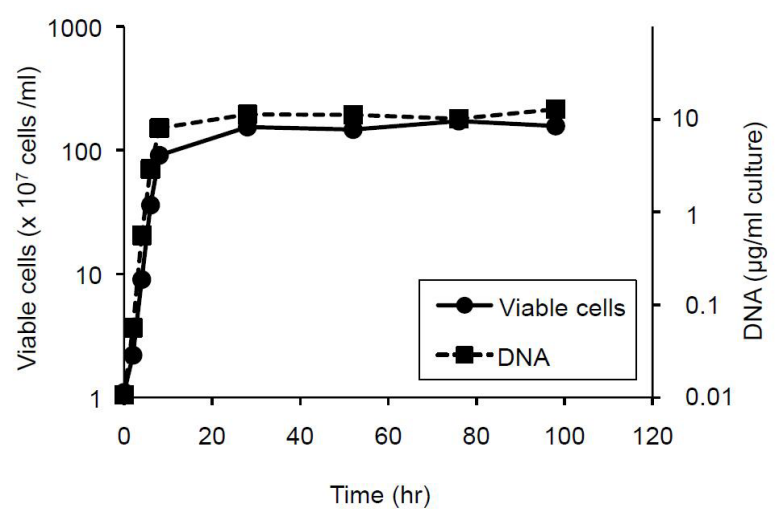

Figure 1. Time-course of the changes in colony-forming units and amount of DNA of lactic acid bacteria Enterococcus faecalis 0831-07. E. faecalis 0831-07 was cultured in MRS liquid media and sampled periodically. Viable bacterial number was calculated by counting the colonies on agar plates on which appropriately diluted samples had been spread and incubated. The amounts of DNA extracted from the bacterial samples were determined by a fluorometric method as described in the Materials and Methods section.

We cultured an Enterococcus faecalis strain (0831-07) in liquid medium and periodically sampled the culture over 5 days. DNA was extracted from the bacterial samples and quantified as described in the Materials and Methods section. During the exponentially growing phase (4-8 h), the amount of DNA increased along with the number of viable cells (Figure 1). At the stationary phase, in which the number of viable bacteria did not increase, the amount of DNA also did not increase (Figure 1). The ratios between the amount of DNA $(\mu \mathrm{g} /$ $\mathrm{mL} \cdot$ culture $)$ and the number of viable cells $\left(\times 10^{7}\right.$ cells/ $\mathrm{mL}$ ) were almost constant (0.059-0.088) for 4 to $100 \mathrm{~h}$ after inoculation. Therefore, when lactic acid bacteria cells proliferate exponentially or even at the stationary phase, it is possible to predict the number of cells on the basis of the amount of DNA.

\subsection{Quantification of DNA in heat-treated lactic acid bacteria}

In most cases, the lactic acid bacteria used for supplements is killed due to heat-treatment or longterm culture during the production process. Therefore, under these conditions, the total number of bacterial cells in the samples is much different from the viable number of cells. The number of viable $E$. faecalis 0831 07 cells cultured at $30^{\circ} \mathrm{C}$ for $28 \mathrm{~h}$ was $1.6 \times 10^{9} \mathrm{cfu} /$ $\mathrm{mL}$. After treatment at $80^{\circ} \mathrm{C}$ for $15 \mathrm{~min}$, the number of viable cells decreased to less than $10 \mathrm{cfu} / \mathrm{mL}$ (Figure $2 \mathrm{~A})$. The amount of DNA extracted from the heattreated cells was $78 \%$ that extracted from non-heattreated samples (Figure 2B). Heat treatment at $80^{\circ} \mathrm{C}$ for 15 min remarkably decreased the number of viable cells, whereas the amount of DNA remained at the same level as before the heat treatment. The size of chromosomal DNA extracted from the heat-treated 

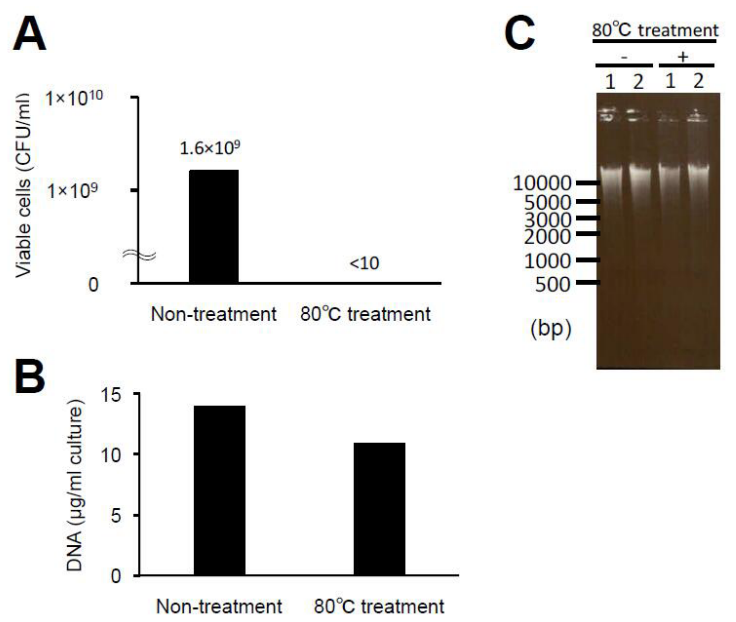

Figure 2. Changes in colony-forming units and amount of DNA after heat-treatment of $\boldsymbol{E}$. faecalis 0831-07. $E$. faecalis 0831-07 was cultured in MRS liquid media for 28 $\mathrm{h}$ and heat-treated at $80^{\circ} \mathrm{C}$ for $15 \mathrm{~min}$. Viable bacterial cell number per milliliter of culture media was calculated by counting the colonies on agar plates on which the samples had been spread and incubated (A). DNA was extracted from the sample and analyzed by DNA quantification (B) or agarose gel electrophoresis (C).

\section{A}

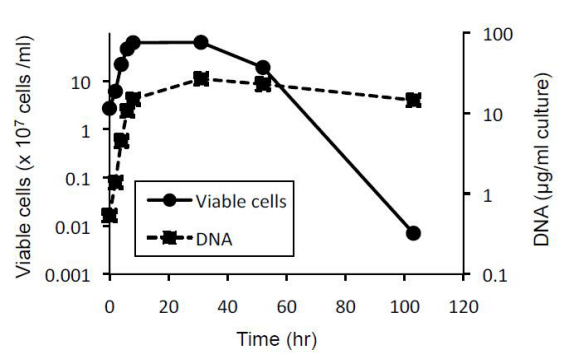

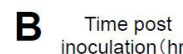

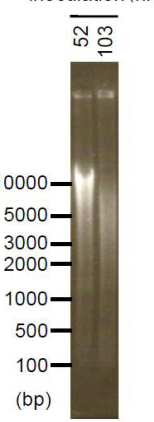

Figure 3. Time-course of the changes of colony-forming units of lactic acid bacteria Lactobacillus paraplantarum 11-1, amount of DNA, and degradation of DNA after longterm culture. Lactobacillus paraplantarum 11-1 was cultured in MRS liquid media and sampled periodically. Viable bacterial cell number was calculated by counting the colonies on agar plates on which the samples had been spread and incubated. The amount of DNA extracted from the bacterial samples was determined by a fluorometric method (A). DNA extracted from $L$. paraplantarum 11-1 was analyzed by agarose gel electrophoresis followed by staining with ethidium bromide. Photography was taken on a UV transilluminator (B). sample was indistinguishable from that extracted from the non-heat-treated samples when analyzed by agarose gel electrophoresis (Figure 2C), suggesting that the heat treatment did not degrade the DNA.

\subsection{The amount of DNA in lactic acid bacterial cells after long-term culture}

L. paraplantarum 11-1 is a lactic acid bacterium with high innate immunity stimulating activity (4). This bacterium is useful for manufacturing of healthy foods. When overnight culture of $L$. paraplantarum $11-1$ in stationary phase was cultured for an additional 4 days, the number of viable bacteria decreased to $1 / 10,000$ that of the stationary phase culture (Figure 3A). Analysis by agarose gel electrophoresis revealed that the DNA in the long-term cultured L. paraplantarum 11-1 degraded into small fragments (Figure 3B). The amount of DNA from the long-term cultured L. paraplantarum 11-1, however, was $97 \%$ that of the stationary phase culture (Figure 1). This indicates that the number of the heat-killed lactic acid bacteria can be estimated by quantifying the DNA.

\subsection{Estimation of total cell number of lactic acid bacteria by DNA determination}

We next attempted to estimate the total number of lactic acid bacterial cells from the amount of DNA extracted from the cells (Table 1). The sizes of the E. faecalis and L. paraplantarum genomes are 3.2 and $3.1 \mathrm{Mbp}$, respectively, which means the amount of one genome of DNA is $3.3 \mathrm{fg}$ and $3.2 \mathrm{fg}$, respectively $(13,14)$ (Table 1). The concentration of the DNA harvested from overnight ( $28 \mathrm{~h}$, stationary phase) cultures of $E$. faecalis and L. paraplantarum was 11 and $27 \mu \mathrm{g} / \mathrm{mL}$ of culture, respectively. The ratio of the total cell number calculated from the DNA amount and the viable cell count was 2.3 and 13, respectively (Table 1). The cell number calculated from the DNA amount was much larger than the viable cell number calculated from the colony count. This is probably caused by the presence of unculturable bacteria (including dead cells) in the samples. Therefore, it is important to note that the total

Table 1. Total cell number of Enterococcus faecalis 0831-07 and Lactobacillus paraplantarum \#11-1 cells estimated by DNA quantification

\begin{tabular}{lccccccc}
\hline Species & Strain & $\begin{array}{c}\text { Genome } \\
\text { size }(\mathrm{Mbp})\end{array}$ & $\begin{array}{c}\text { Calculated } \\
\text { amount of } \\
\text { genome } \\
\text { DNA/cell }(\mathrm{fg})\end{array}$ & $\begin{array}{c}\text { Determined } \\
\text { amount of DNA } \\
(\mu \mathrm{g} / \mathrm{mL} \text { culture })\end{array}$ & $\begin{array}{c}\text { Cell number } \\
\text { calculated from } \\
\text { DNA amount } \\
\left(\times 10^{9} \mathrm{CFU} / \mathrm{ml} \text { culture }\right)\end{array}$ & $\begin{array}{c}\text { Viable cell } \\
\text { number } \\
\left(\times 10^{9} \mathrm{CFU} / \mathrm{mL} \text { DNA amount/Viable }\right. \\
\text { culture })\end{array}$ & $\begin{array}{c}\text { Cell number } \\
\text { calculated from } \\
\text { cell number }\end{array}$ \\
\hline $\begin{array}{l}\text { Enterococcus } \\
\text { faecalis } \\
\begin{array}{l}\text { Lactobacillus } \\
\text { paraplantarum }\end{array}\end{array}$ & $0831-07$ & 3.2 & 3.3 & 11 & 3.4 & 1.5 & 2.3 \\
\hline
\end{tabular}

The cells were cultured in MRS medium at $30^{\circ} \mathrm{C}$ for $28 \mathrm{~h}$. The amount of genome DNA in cells was calculated from the genome sizes of $E$. faecalis and L. paraplantarum. The DNA amounts were determined as described in the Materials and Methods section. Molecular weight of one pair of deoxynucleotides is 616 . Avogadro's constant is $6.02 \times 10^{23}$. 
cell number estimated by DNA quantification is always much larger than that of viable cells.

\section{Conclusion}

In the present study, we showed that the amount of DNA in lactic acid bacteria was maintained at a certain level, even though almost of the cells were killed by heat-treatment or by long-term culture. This indicates that the number of lactic acid bacteria can be estimated on the basis of the amount of DNA in fermented foods or supplements.

\section{Acknowledgements}

We thank Mari Maeda (Genome Pharmaceuticals Institute Co., Ltd, Tokyo, Japan) for her technical assistance in quantifying DNA amount. The project was supported by JSPS KAKENHI grant number JP15H05783 (Scientific Research (S) to KS), and JSPS KAKENHI grant number JP17K08288 (Scientific Research (C) to YM). The project was also supported by Genome Pharmaceuticals Institute Co., Ltd (Tokyo, Japan) and Antenna Co., Ltd (Fukuoka, Japan).

\section{References}

1. Lynch KM, Zannini E, Coffey A, Arendt EK. Lactic acid bacteria exopolysaccharides in foods and beverages: Isolation, properties, characterization, and health benefits. Annu Rev Food Sci Technol. 2018; 9:155-176.

2. Morelli L. Yogurt, living cultures, and gut health. Am J Clin Nutr. 2014; 99:1248S-1250S.

3. Trinder M, Bisanz JE, Burton JP, Reid G. Probiotic lactobacilli: a potential prophylactic treatment for reducing pesticide absorption in humans and wildlife. Benef Microbes. 2015; 6:841-847.

4. Nishida S, Ishii M, Nishiyama Y, Abe S, Ono Y, Sekimizu K. Lactobacillus paraplantarum 11-1 isolated from rice bran pickles activated innate immunity and improved survival in a silkworm bacterial infection model. Front Microbiol. 2017; 8:436.

5. Nishida S, Ono Y, Sekimizu K. Lactic acid bacteria activating innate immunity improve survival in bacterial infection model of silkworm. Drug Discov Ther. 2016; 10:49-56.

6. Ishii M, Matsumoto Y, Nishida S, Sekimizu K. Decreased sugar concentration in vegetable and fruit juices by growth of functional lactic acid bacteria. Drug Discov Ther. 2017; 11:30-34.

7. Ishii M, Nishida S, Kataoka K, Nishiyama Y, Abe S, Sekimizu K. Lactic acid bacteria of the Leuconostoc genus with high innate immunity-stimulating activity. Drug Discov Ther. 2017; 11:25-29.

8. Matsumoto Y, Ishii M, Sekimizu K. An in vivo invertebrate evaluation system for identifying substances that suppress sucrose-induced postprandial hyperglycemia. Sci Rep. 2016; 6:26354.

9. Salma M, Rousseaux S, Sequeira-Le Grand A, Alexandre H. Cytofluorometric detection of wine lactic acid bacteria: application of malolactic fermentation to the monitoring. J Ind Microbiol Biotechnol. 2013; 40:63-73.

10. Whiting M, Crichlow M, Ingledew WM, Ziola B. Detection of Pediococcus spp. in brewing yeast by a rapid immunoassay. Appl Environ Microbiol. 1992; 58:713-716.

11. Rodriguez SB, Thornton RJ. Use of flow cytometry with fluorescent antibodies in real-time monitoring of simultaneously inoculated alcoholic-malolactic fermentation of Chardonnay. Lett Appl Microbiol. 2008; 46:38-42.

12. Zhao Y, Xiang S, Dai X, Yang K. A simplified diphenylamine colorimetric method for growth quantification. Appl Microbiol Biotechnol. 2013; 97:50695077.

13. Liu L, Li P. Complete genome sequence of Lactobacillus paraplantarum L-ZS9, a probiotic starter producing class II bacteriocins. J Biotechnol. 2016; 222:15-16.

14. Paulsen IT, Banerjei L, Myers GS, et al. Role of mobile DNA in the evolution of vancomycin-resistant Enterococcus faecalis. Science. 2003; 299:2071-2074.

(Received April 16, 2018; Accepted April 29, 2018) 